\title{
Stress Induced Alterations in Striatal GABAA Receptor Complex
}

\author{
Ming-Yu ZHANG*, Tsuneichi HASHIMOTO and Kinya KURIYAMA* \\ Department of Pharmacology, Kyoto Prefectural University of Medicine. \\ Kamikyo-ku, Kyoto 602, Japan \\ Accepted February 7. 1990
}

\begin{abstract}
The effect of cold-immobilized stress on the $\gamma$-aminobutylic acid (GABA)/ benzodiazepine (BZP) receptor complex in the rat striatum was examined. The stressful manipulation induced a significant decrease in the amount of $\left[{ }^{3} \mathrm{H}\right]$ muscimol binding sites in the striatal particulate fraction. On the other hand, $\left[{ }^{3} \mathrm{H}\right] \mathrm{fluni}-$ trazepam (FLN) binding and the enhancing effect of FLN or secobarbital on the $\left[{ }^{3} \mathrm{H}\right]$ muscimol binding to the striatal particulate fraction were not influenced by the stress treatment. These results suggest that cold-immobilized stress may selectively change $G A B A_{A}$ receptor binding without altering $B Z P$ receptor binding as well as the functional coupling between $G_{A B A_{A}}$ and $B Z P$ receptors.
\end{abstract}

We previously reported that the application of cold and immobilization stress to rats induced a significant increase in $\gamma$-aminobutylic acid (GABA) contents as well as an elevation of L-glutamic acid decarboxylase (GAD) activity in the striatum and hypothalamus (1). In this study, we have attempted to examine whether or not the cold and immobilization stress affects the functions of the $\mathrm{GABA}_{A}$ receptor complex in the rat striatum.

Male Wistar rats weighing $200-250 \mathrm{~g}$ were confined individually in a metallic restraint stress-cage and kept in a water bath at $25^{\circ} \mathrm{C}$ for $3 \mathrm{hr}$ so that the xiphoid process of the rat was immersed (2). Rats were sacrificed by decapitation immediately after the stress treatment, and it was employed between 11:00-12:00 a.m. to avoid possible circadian variations in receptor functions. The dissected striata were homogenized in $20 \mathrm{ml}$ of $50 \mathrm{mM}$ Tris-citrate buffer ( $\mathrm{pH}$ 7.1) with a Polytron homogenizer (setting $6,30 \mathrm{sec}$ ) and centrifuged at $48.000 \times \mathrm{g}$ for $20 \mathrm{~min}$. After repeating the washing of the particulate fraction by resuspending and centrifuging three times, it was suspended in $50 \mathrm{mM}$ Tris-

\footnotetext{
* Present address: Department of Pharmacology. Anhui Institute of Medical Sciences, 1 Young Hong Road, Hefei, Anhui, China.

- To whom correspondence should be addressed.
}

citrate buffer $(\mathrm{pH} 7.1)$ and used for the following experiments as the "particulate fraction". The striatal particulate fraction was incubated with $\left[{ }^{3} \mathrm{H}\right]$ muscimol $(20.0 \mathrm{Ci} /$ mmol, New England Nuclear) in $1 \mathrm{ml}$ of 50 $\mathrm{mM}$ Tris-citrate buffer $(\mathrm{pH} 7.1)$ at $2^{\circ} \mathrm{C}$ for $45 \mathrm{~min}$ in the presence or absence of $10^{-6} \mathrm{M}$ flunitrazepam or $10^{-3} \mathrm{M}$ secobarbital according to the method of Yoneda et al. (3). In the case of $\left[{ }^{3} \mathrm{H}\right]$ flunitrazepam $\left(\left[{ }^{3} \mathrm{H}\right] \mathrm{FLN}\right.$, $81.8 \mathrm{Ci} / \mathrm{mmol}$. New England Nuclear) binding. the striatal particulate fraction was incubated with 0.72 pmol of [ $\left.{ }^{3} \mathrm{H}\right] \mathrm{FLN}$ in $1 \mathrm{ml}$ of $50 \mathrm{mM}$ Tris-citrate buffer at $2^{\circ} \mathrm{C}$ for $60 \mathrm{~min}$. The specific bindings of $\left[{ }^{3} \mathrm{H}\right]$ muscimol and $\left[{ }^{3} \mathrm{H}\right] \mathrm{FLN}$ were calculated by subtracting the amount of non-specific binding found in the presence of $1 \mathrm{mM}$ non-labeled GABA and $100 \mu \mathrm{M}$ clonazepam from each total binding. respectively. For Scatchard analysis, the striatal particulate preparations were incubated with 5 pmol of $\left[{ }^{3} \mathrm{H}\right]$ muscimol in $0.5 \mathrm{ml}$ of $50 \mathrm{mM}$ Tris-citrate buffer containing varying concentrations of nonradioactive muscimol. Each of the data values for the Scatchard analysis was evaluated by the method of Rosenthal (4).

Following 3-hr immobilization stress, animals exhibited ataxia and loss of the righting reflex. The amount of specific $\left[{ }^{3} \mathrm{H}\right]$ muscimol binding to the striatal particulate fraction obtained from these animals showed a sig- 
nificant decrease. whereas no such alteration was observed in the specific binding of $\left[{ }^{3} \mathrm{H}\right]$ FLN to the striatal particulate fraction (Fig. 1). Since it has been well-established that FLN and secobarbital enhance the GABA receptor binding (5), we attempted to examine the enhancing effects of FLN and secobarbital on striatal $\left[{ }^{3} \mathrm{H}\right]$ muscimol binding. However, no significant changes were detected in the enhancing effects of FLN $\left(10^{-5}\right.$ $\mathrm{M}: 102.0 \pm 3.1$ vs. $98.3 \pm 3.4)$ and secobarbital $\left(10^{-5} \mathrm{M}: 156.8 \pm 4.3\right.$ vs. $152.1 \pm 6.8$; indicated as a percent of the control) on $\left[{ }^{3} \mathrm{H}\right]$ muscimol binding following the application of stress. To elucidate the nature of the decrease of $\left[{ }^{3} \mathrm{H}\right]$ muscimol binding induced by stress, we analyzed the binding by Scatchard plot. As shown in Table 1, the 3 -hr stress induced significant decreases in both the dissociation constant $\left(K_{d}\right)$ and the values for the number of binding sites $\left(\mathrm{B}_{\max }\right.$ ) at the high-affinity site of $\left[{ }^{3} \mathrm{H}\right]$-muscimol binding. On the other hand, immobilization stress had no influence on the low affinity site of $\left[{ }^{3} \mathrm{H}\right]$ muscimol binding in the striatum.

It has been reported that application of an immobilization stress to animals induced a significant alteration in the metabolism and/ or function of various putative neurotransmitters in the central nervous system. For example, it has been reported that immobilization stress induces significant reductions in the endogenous levels of monoamines such as noradrenaline, adrenaline (6). dopamine (7) and 5-hydroxytryptamine (8), with a concomitant acceleration of their metabolic turnover in vivo $(9,10)$. In contrast, it has been demonstrated that the
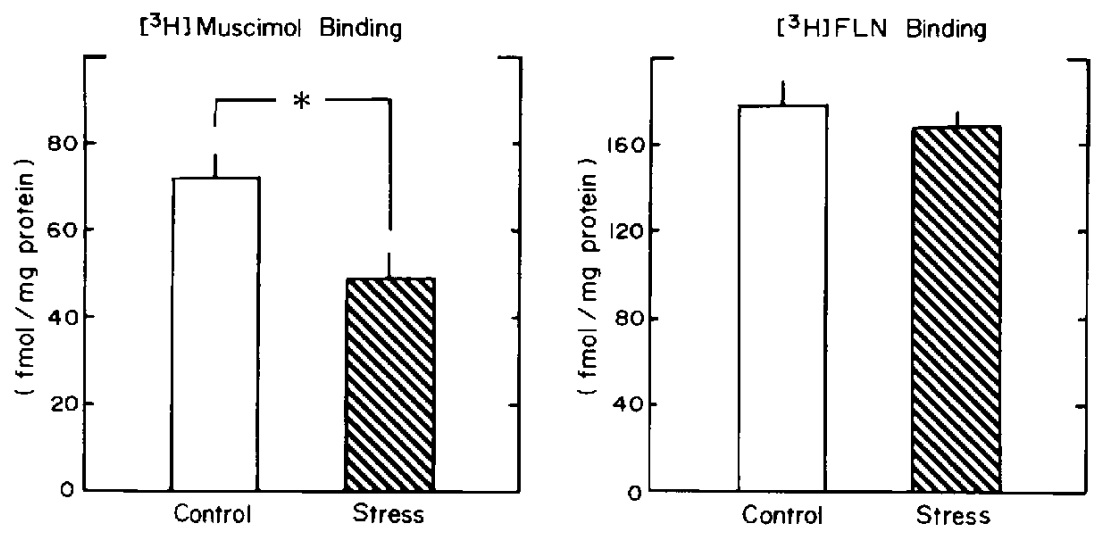

Fig. 1. Effect of immobilized stress on striatal $\left[{ }^{3} \mathrm{H}\right]$ muscimol and $\left[{ }^{3} \mathrm{H}\right]$ flunitrazepam $\left(\left[{ }^{3} \mathrm{H}\right]\right) \mathrm{FLN}$ ) bindings in rats. Striatal particulate fractions were incubated with $1.8 \mathrm{nM}\left[{ }^{3} \mathrm{H}\right]$ muscimol and $0.72 \mathrm{nM}\left[{ }^{3} \mathrm{H}\right] \mathrm{FLN}$, respectively. Each bar represents the mean \pm S.E.M. obtained from 8 to 14 separate experiments. "P< 0.05 , compared with the control value by Student's $t$-test.

Table 1. Stress-induced changes in kinetic parameters for $\left[{ }^{3} \mathrm{H}\right]$ muscimol binding to rat striatal particulate fraction

\begin{tabular}{lcccc}
\hline & \multicolumn{2}{c}{ High affinity } & \multicolumn{2}{c}{ Low affinity } \\
\cline { 2 - 5 } & $\begin{array}{c}K_{d} \\
(n M)\end{array}$ & $\begin{array}{c}B_{\max } \\
\text { (pmol/mg protein) }\end{array}$ & $\begin{array}{c}K_{\mathbf{d}} \\
(n M)\end{array}$ & $\begin{array}{c}B_{\max } \\
\text { (pmol/mg protein) }\end{array}$ \\
\hline Control & $40.6 \pm 5.2$ & $1.01 \pm 0.11$ & $649.3 \pm 75.5$ & $6.48 \pm 0.69$ \\
Stress & $17.2 \pm 4.8^{*}$ & $0.52 \pm 0.06^{*}$ & $1073.9 \pm 443.1$ & $6.59 \pm 2.52$ \\
\hline
\end{tabular}

Specific bindings of $\left[{ }^{3} \mathrm{H}\right]$ muscimol to the striatal particulate fraction were determined with various concentrations of non-labeled muscimol $(10-300 \mathrm{nM})$ in the presence or absence of $1 \mathrm{mM} G A B A$. Each value represents the mean \pm S.E.M. obtained from 3 separate experiments. ${ }^{*} \mathrm{P}<0.05$, compared with the respective control value by Student's $t$-test. 
application of cold and immobilization stress to rats induces a significant increase in the striatal and hypothalamic GABA contents (1). Furthermore, it has been shown in this study that the activity of GAD is elevated in both cerebral areas with a concomitant decrease in the content of glutamic acid, the substrate for GAD to form GABA. Since the elevation of GABA in the striatum was found to be the highest among various central structures examined in these animals, the striatum was used in this study to determine whether or not the immobilization stress alters the functions of the GABA/BZP receptor complex. It has been found that cold and immobilization stress induces a significant decrease in $\left[{ }^{3} \mathrm{H}\right.$ ] muscimol binding to $\mathrm{GABA}_{A}$ receptors in striatal preparations, while no such alterations are detected in the $\left[{ }^{3} \mathrm{H}\right] \mathrm{FLN}$ binding to BZP receptors as well as on the enhancing effect of FLN or secobarbital (5. 11) on $\left[{ }^{3} \mathrm{H}\right]$ muscimol binding. Furthermore, the Scatchard analyses of [3H]muscimol binding have revealed that the reduction in $\left[{ }^{3} \mathrm{H}\right]$ muscimol binding is due to the decrease in both the $K_{a}$ and $B_{\max }$ values at the high affinity binding sites. Another experiment showed that there was a significant suppression of $\mathrm{KCl}$-evoked release of $\left[{ }^{3} \mathrm{H}\right] \mathrm{GABA}$ by muscimol and $\hat{o}$-aminolevulinic acid in striatal slices from stress-treated animals (12). It is well-accepted that a down regulation in the number of receptors may occur upon exposure to a high concentration of neurotransmitters or hormones that activate these receptors (13). Considering these results, it is likely that the application of cold and immobilization stress induces an increase of GABA in some cerebral areas such as the striatum and hypothalamus as well as alteration at $\mathrm{GABA}_{\boldsymbol{A}}$ receptors, possibly by a down regulation mechanism. while it enhances the negative feedback control on the release of GABA from its nerve terminals by changing the function of presynaptic autoreceptors. Furthermore, the present results suggest that the decrease in $B_{\max }$ value contributes more significantly to the stressinduced decrease of striatal $\left[{ }^{3} \mathrm{H}\right]$ muscimol binding than that in the $K_{d}$ value. Although the molecular mechanism underlying such a selective desensitization at $\mathrm{GABA}_{\mathrm{A}}$ receptors is not clear at present, possible involvement of such a functional change at cerebral $G A B A_{A}$ receptors during cold and immobilization stress should be emphasized.

Acknowledgment: This work is supported in part by an international fellowship to Ming-Yu Zhang from the Takeda Science Foundation (Japan).

\section{References}

1 Yoneda, Y., Kanmori, K., Ida, S. and Kuriyama, K.: Stress-induced alterations in metabolism of $\gamma$ aminobutyric acid in rat brain. J. Neurochem. 40, 350-360 (1983)

2 Nakagawa, K. and Kuriyama, K.: Effect of taurine on alteration in adrenal functions induced by stress Japan. J. Pharmacol. 25, 737-746 (1975)

3 Yoneda, Y. and Kuriyama, K.: Some characteristics of $\left[{ }^{3} \mathrm{H}\right]$ muscimol binding to synaptic membrane from rat brain. Brain Res. 197, 554560 (1980)

4 Rosenthal, H.E.: A graphic method for the determination and presentation of binding parameters in a complex system. Anal. Biochem. 20, 525-532 (1967)

5 Willow, M. and Johnston, G.A.R.: Enhancement by anesthetic and convulsant barbiturates of GABA binding to rat brain synaptosomal membranes. J. Neurosci. 1, 364-367 (1981)

6 Kvetnansky, R., Sun, C.L., Torda, T. and Kopin, I.J.: Plasma epinephrine and norepinephrine levels in stressed rat. Effect of adrenolectomy. Pharmacologist 19, 241-251 (1977)

7 Herve, D., Tassin, J.P., Barthelemy, C., Blanc, G., Lavielle, S. and Glowinski, J.: Difference in the sensitivity of mesocortical dopaminergic neurons to stress in the BALB/C mice and $\mathrm{C} 57 \mathrm{BL} / 6$ mice. Life Sci. 25, 1659-1664 (1979)

8 Gal, E.M., Hwater, R.D. and Milland, S.A.: Studies on the metabolism of 5-hydroxytryptamine (serotonin) IV. Hydroxylation and amines in cold-stressed reserpinized rat. Proc. Soc. Exp, Biol. Med. 128, 412-415 (1968)

9 Okuda, C., Saito, A., Miyazaki, M. and Kuriyama, K.: Alteration of the turnover of dopamine and 5hydroxytryptamine in the rat brain associated with hypothermina. Pharmacol. Biochem. Behav. 24, 78-83 (1986)

10 Thierry, A.M., Javoy, F., Glowinski, J. and Kety, S.S.: Effects of stress on the metabolism of norepinephrine, dopamine and serotonin in the central nervous system of the rat. I. Modifications of norepinephrine turnover. J. Pharmacol. Exp. Ther. 163, 163-171 (1968)

11 Skolnick, P., Rice, K.C., Barker, J.L. and Paul, S.M.: Interaction of barbiturates with benzo- 
diazepine receptors in the central nervous system. Brain Res. 233, 143-156 (1982)

12 Kuriyama, K., Kanmori, K., Taguchi, J. and Yoneda, Y.: Stress-induced enhancement of suppression of $\left[{ }^{3} \mathrm{H}\right] \mathrm{GABA}$ release from striatal slices by presynaptic autoreceptor. J. Neurochem. 42, 943-950 (1984)

13 Raff, M.: Self regulation of membrane receptors. Nature 259, 256-266 (1976) 